\title{
Beauvoir in China
}

And what is happening in China? That is a question I would really like to be able to answer.

SIMONE DE BEAUVOIR, Tout compte fait ${ }^{1}$

Rather than speculate any further about what Beauvoir "would have felt" or might have done, suppose we go back to what she did do, and did say. I want to conclude my investigation of things people find embarrassing about Simone de Beauvoir, things she said that "we wouldn't say now," by looking at La longue marche: essai sur la Chine (1957). ${ }^{2}$ As my own book's long march draws to a close, I note that the corners of Beauvoir's œuvre are increasingly wellexplored, with unpublished writings finding their way into print and nearly everything available in English: even the prestigious Pléiade series has finally admitted her to the French literary canon by devoting two volumes to her work. But Beauvoir scholars still seem to shy away from her book about China, and it seems worth thinking about why. ${ }^{3}$

\section{An Essay on China}

La longue marche began as a report on a six-week trip Beauvoir and Sartre took in 1955, in response to Chou En-Lai's invitation at the Bandung Conference of non-aligned nations, where the first premier of the People's Republic had challenged the world to "come and see" what the Chinese revolution had achieved. Beauvoir and Sartre, along with many others on the European left, took him up

1 "Et que se passe-t-il en Chine? Voilà une question à laquelle je voudrais bien pouvoir répondre" (Tout compte fait [hereinafter TCF], 562, All Said and Done [hereinafter ASD ], 443).

2 The English version appeared the following year; the subtitle was not "an essay on China" but (in the US) "A Book on China" and in the UK "An Account of Modern China." The translation, by Austryn Wainhouse (better-known for his unexpurgated translations of the Marquis de Sade), is otherwise faithful and I have used it below, with a few minor alterations.

3 One strong exception is a very good overview article by Sandrine Dauphin, "En terre d'Icarie: les voyages de Simone de Beauvoir et de Jean-Paul Sartre en Chine et à Cuba” (2004). William McBride, in "The Postwar World According to Beauvoir," now does a good job of providing general historical context, drawing comparisons with L'Amérique au jour le jour 1947 and with the present day, and a brief but helpful discussion can be found in Karen Vintges, "Surpassing Liberal Feminism." 
on it: they were among some 1,500 foreign delegates to the festivities celebrating the anniversary of the revolution in October of that year. As Leiris, who also went, observed, this was a "voyage engagé" — a committed, engaged voyage: "To participate in this organized delegation was implicitly to declare oneself a sympathizer."

What kind of book is La longue marche? Beauvoir calls it an "essay on China," an "étude" or study, and it runs to five hundred pages, with chapters on "peasants," "the family," "industry," "culture," and "the defensive struggle," as well as "the discovery of Peking," "the first of October," and "cities of China." To pigeonhole it as "travel writing" does not really work, despite some familiar gestures of that genre. As Sandrine Dauphin writes: "To act as a witness did not simply mean to describe what they had seen. It was a question of explaining the context of China's revolutions, and analyzing them." ${ }^{5}$ Dauphin quotes from Beauvoir's memoirs: "I have already written the story of my journey to China. It was not like my other trips. It was not just a wandering, not an adventure, not a journey made just for the experience, but a field study in which caprice played no part.... It is useless to try to describe this country: it demands to be explained."6 Beauvoir does insist on the primacy of what she saw with her own eyes, and seems scrupulous to record exactly where she went, what she saw, and what she thought about it at the time. However, this is not by any means "China Day by Day." In contrast to her book about the US, and to the way she describes her travels in her memoirs, the travelogue portions of $L a$ longue marche are severely de-personalized, almost as if to say, my sensibilities are not the point here. Also, she draws just as heavily on what Americans call "book learning." Upon their return to France, Sartre contented himself with giving a few interviews and writing a brief journalistic piece, ${ }^{7}$ and Leiris's impressions found their way diagonally into La règle $\mathrm{du} \mathrm{jeu}$, his rigorous and idiosyncratic experiment in radical introspection. Beauvoir, however, embarked on a sustained project of interdisciplinary research, comparable to the library work that had prepared her to write The Second Sex, and that she'd later repeat

4 " $[\mathrm{P}]$ articiper à cette tournée effectuée en délégation était implicitement se déclarer sympathisant" (Michel Leiris, Fibrilles, 84). See also Alex Hughes, "The Seer (Un)seen: Michel Leiris's China."

5 "Témoigner ne signifiait pas seulement décrire ce qu'ils avaient vu. Il s'agissait d'expliquer le contexte de ses révolutions, de les analyser" (119).

6 "J'ai raconté mon voyage en Chine. Il ne ressembla pas aux autres. Ce ne fut ni un vagabondage, ni une aventure, ni une expérience, mais une étude, menée sur place sans caprice ... [I]l est vain de prétendre décrire ce pays: il demande à être expliqué" (Dauphin 119, quoting $L a$ force des choses [hereinafter $F C h$ ], 2:78-9).

7 Sartre, "La Chine que j'ai vu." 
when writing La vieillesse (Old Age). La longue marche bears constant traces of her reading in history, philosophy, sociology, economics, contemporary journalism, and both classic and contemporary Chinese literature, including fiction and drama. La longue marche is also, from its opening pages, a polemic, a no-holds-barred response to French right-wing writers who had shown suspicion and hostility toward the Chinese revolution. As such it belongs with her other political writing — for example her 1954 essay "La pensée de droite aujourd'hui" (Right-Wing Thought Today) ${ }^{8}$ - and her editorial work for Les Temps Modernes.

Beauvoir is honest about her initial confusion and the limits of officially managed tourism, and she was honest afterward that she thought La longue marche was not very good, that the task she had set herself was too hard. She is quite clear about the limits of what she was able to find out, quite aware that the sights she saw had been carefully prepared for her-as she says, her hosts told her as much. She did not like every single thing she saw, and she did not believe everything she was told: the book is definitely colored by optimism, but "it remains to see" what will happen. Still, La longue marche is very definitely a political intervention in a way that The Second Sex and Pour une morale de l'ambiguité really were not. Despite the vicious red-baiting with which $L a$ longue marche was received, its primary commitment was not to communism as such, but to anti-colonialism and to the Third World movement which, at least initially, was trying to be beholden to neither bloc. She writes from the subject position of the European non-aligned, internationalist left, the position associated with Richard Wright and Frantz Fanon that is sometimes now referred to as "Bandung humanism."

Also, while there is a great deal about women in the book, I should say that this is not, or not mainly, a book about women: issues of gender equality, and the effects on women of the traditional Chinese family, arise within the context of a broader story of cultural transformation. This is not something new for Beauvoir, as we have seen.

A review of the timeline may be in order here. La longue marche is situated well after The Second Sex, but well before Beauvoir's sustained period of public feminist activism in the 1970s. It stands at the beginning of the period I discussed at the start of chapter 5 , the time when her activism on behalf of the people of Algeria meant other issues had to take a back seat: in La force des choses, the section where she describes her trip to China and the section where she describes the process of writing about it are separated by some of her

8 First published in Les Temps Modernes in 1954, "La pensée de droite aujourd'hui" was collected the following year in Privilèges. It is translated in Political Writings of Simone de Beauvoir. 
strongest pages about the crisis in the Maghreb, the massacres she compares to Nazi atrocities at Oradour, and the complicity with the oppressors on the part of almost all the French, including the French Communist party. ${ }^{9}$ When Beauvoir went to China, she had not yet been to Cuba-she and Sartre would go there five years later. He had already been to the Soviet Union-she had not; but she had already written Les mandarins (1954), a novel which explores in great complexity the responsibilities of intellectuals and the ethical difficulties of speaking the critical truth about a regime one supports. The question of whether socialist fellow-travelers should speak openly against the labor camps in the Soviet Union had already been resolved in the affirmative, both in literature and in life.

The paucity of in-depth scholarship about La longue marche may seem surprising given the book's importance to Beauvoir herself. She noted in her autobiography that writing it gave her the perspective and the tools to see beyond the "developed" world: "In writing it I acquired schemata, keys, which helped me to understand other underdeveloped countries."10

Comparing my civilization with another, very different one, I discovered the singularity of traits which had seemed common to me. Simple words, like peasant, field, village, town, family, did not have at all the same meaning in Europe or in China ... [T] his trip swept away my old reference points. Until now, in spite of my reading and a few casual glances at Mexico and Africa, I had taken the prosperity of Europe and the United States as the norm; the Third World only existed vaguely on the horizon. The Chinese masses unbalanced the planet for me; the Far East, India, Africa, their famine [disette], became the truth of the world, and our western comfort a narrow privilege. ${ }^{11}$

9 For the trip, see FCh 2:78-9, FCirc 344-46. For the writing of the book, see FCh 2:94-6, FCirc 357-59.

10 “J'ai acquis en l'écrivant des schémas, des clés, qui m’ont servi à comprendre les autres pays sous-développés" (FCh 2:96, FCirc 359, translation altered).

11 "Personellement, je tirai de cette étude un grand profit. Confrontant ma civilisation avec une autre, fort différente, je découvris la singularité des traits qui m’avaient paru communs; des mots simples, comme paysan, champ, village, ville, famille, n'avaient pas du tout le même sens en Europe ou en Chine; la vision de mon propre environnement s'en trouva rafraîchie.... D'une manière générale, ce voyage avait balayé mes anciens repères. Jusqu'alors, malgré mes lectures et quelques vues cavalières sur le Mexique et l'Afrique, c'était la prospérité de l'Europe et des usA que j'avais prise comme norme, le Tiers Monde n'existant que vaguement à l'horizon. La masse chinoise déséquilibra pour moi la planète; l'Extrême-Orient, les Indes, l'Afrique, leur disette, devinrent la vérité du monde, et notre confort occidental un étroit privilège" (FCh 2:96, FCirc 358-59, translation altered). 
She even wrote in 1963, in a retrospective assessment of The Second Sex, that if she were to write that book "today," she'd take the more materialist approach she'd used in La longue marche, and would "ground the idea of Other not on an idealist, a priori struggle of consciousnesses, but on scarcity and need; I did that in La longue marche, when I spoke of the ancient subjection of Chinese women." ${ }^{2}$ Nonetheless, La longue marche is the least widely read of Beauvoir's texts today, and it is overhung by an aura of embarrassment, for two sorts of reasons.

One set of reasons has to do with the Cold War. When the book appeared, it was strongly attacked both in France and in the US. Beauvoir and other "fellow-travelers" were described as duped by the Communists, or accused of knowingly covering up for Mao's failures and excesses, or both at once. Even today, her argument that the Chinese experiment was "passionnante" (thrilling), and that Chairman Mao was succeeding in feeding the Chinese people, does not go down well in the West and especially in the US, where Mao is often thought of as simply a monster. ${ }^{13}$

The other embarrassment, of course, has to do with the fact that La longue marche fails to praise Chinese culture, Chinese "difference," in the way Western multiculturalism, and especially multiculturalist feminism, would now seem to demand. There is indeed a great deal in La longue marche that "we wouldn't say now," and (unlike L'Amérique au jour le jour 1947) it may not repay a lot of close reading. But I do think that if we sweep it under the rug we're missing an important puzzle piece, and a further chance to redress what I've seen as three major distortions of Beauvoir's reception in the US: our tendency to reduce cultural and historical differences to "race" (seen almost entirely in terms of Black and white); our failure to see how fully she was a woman of the Left; and our reluctance to appreciate her interest in empirical inquiry, in facts, not merely as an illustration or adjunct to philosophy or theory, but facts in themselves, as an urgent way of knowing the world.

As you might expect, I'm planning to show that a simple dismissal of Beauvoir's long and detailed study as "orientalizing" is an unhelpful oversimplification. But I do not intend by any means to argue that La longue marche is a

12 "[J]e prendrais dans le premier volume une position plus matérialiste. Je fonderais la notion d'autre et le manichéisme qu'elle entraîne non sur une lutte a priori et idéaliste des consciences, mais sur la rareté et le besoin: je l'ai fait dans La longue marche, quand j'ai parlé de l'antique asservissement des Chinoises" (FCh 1:267, FCirc 202, translation altered).

13 For a discussion of monolithic American views, see Some of Us: Chinese Women Growing Up in the Mao Era, edited by Yueping Zhong, Wang Zheng, and Bai Di, and see also Daniel Vukovich, "China in Theory: The Orientalist Production of Knowledge in the Global Economy." 
neglected masterpiece. ${ }^{14}$ The book is certainly wrong about many things, and was outdated almost before it appeared by the rush of events. Early in the book Beauvoir says, "One of the major objections that is likely to be leveled against this book is that it will be out of date (dépassé) tomorrow. That is very true." She wasn't wrong. ${ }^{15}$ Another reason it is not much read is that it is quite boring. It's full of numbers, detailed objective descriptions of factories, villages, nurseries, etc., accounts of the Five-Year Plan, a long discussion of the process of wood-block printing, and so on. Like many visitors to China, Beauvoir complained about the long, factual lectures her group was given at every stopping point, but sometimes the style seems to have been contagious. And it's boring on purpose; it deliberately disavows the "picturesque."16 This is not travel writing, not about charm or "local color," it's about hunger, scarcity, the contrast between the past suffering of the Chinese people under semi-colonialism, and the efforts toward modernization by which the Chinese were, she thought, building a better society. Beauvoir makes it clear in her opening pages that she is not visiting "the mysterious East." "J'étais indifférente à la Chine ancienne," she says.

Ancient China did not interest me much. For me, China was this patient epic that starts in the dark days of La condition humaine and ends on the First of October, 1949, in an apotheosis on the Tien An Men; China, for me, was this stirring and reasonable revolution which had not only delivered peasants and workers from exploitation, but had rid an entire land of the foreigners. ${ }^{17}$

14 Early responses have showed me I need to be clear about this. If readers are looking to discover Beauvoir beyond her usual canon, I would suggest beginning instead with L'Amérique au jour le jour 1947 or Les belles images.

15 'Un des reproches majeurs qu'on pourrait adresser à ce livre, c'est que demain il sera dépassé: je le sais; mais l'histoire qui se fait en Chine est assez passionnante pour que les différents moments méritent d'être enregistrés" (La longue marche 25, The Long March 28). In 1963 she judged parts of it "déjà caducs," already obsolete (FCh 2:96, FCirc 359, translation altered).

16 Jean Jamin's introduction to Leiris's Journal de Chine aptly describes something similar, Leiris's deliberate suppression of "le rêve," of imagination, in favor of meticulously empirical "field notes" (11-13). Beauvoir's own gradual disavowal of "the picturesque" is marked also in Les mandarins: Henri sets off for Portugal yearning for the warmth and beaches of the East; what he finds is famine, and Salazar, and desperation. (The story is autobiographical and Beauvoir tells it elsewhere in the first person.) Sartre's introduction to Cartier-Bresson's book of photographs, D'une Chine à l'autre, begins: “À l'origine du pittoresque il y a la guerre" (the picturesque has its origin in war) (7).

17 "J'étais indifférente à la Chine ancienne. La Chine, pour moi, c'était cette patiente épopée qui commence aux jours sombres de La condition humaine et s'achève en apothéose le $\mathrm{r}^{\mathrm{er}}$ 
"Old China did not interest me"-indeed, she does not disguise that she found Chinese painting incomprehensible and all pretty much the same, and Chinese public monuments for the most part very ugly. China for her was a site of struggle.

By 1955, the Cold War polarization Beauvoir described in L'Amérique au jour le jour 1947 had reached new levels, in France as well as the US. Nearly all Western accounts of China in the 1950s were embedded in a high stakes Politics of Truth that bordered on hysteria. ${ }^{18}$ And since then, a vast literature has continued to pour withering scorn on several generations of Western travelers to China. Beauvoir comes in for a great deal of mockery, lumped in with such American writers as Edgar Snow, Agnes Smedley, and Anna Louise Strong, and the New Zealander Rewi Alley, who was an important source of information for her both in person (during her visit) and through his books. When The Long March appeared in English, one G.F. Hudson, writing for Encounter, began his review: "To-day the passionate pilgrims in search of the new Jerusalem go not to Moscow, but to Peking."19 The whole piece is so nasty, and so scornful of Beauvoir for having dared to write about China in the first place, that I cannot stop myself from reminding you that Encounter was funded by the CIA. ${ }^{20}$ (So much, once again, for my own attempt to get beyond Cold War politics.) Or see a very long very angry and dismissive response by the French comparative literature scholar René Étiemble: "Based on ignorance and arrogance, stuffed with as many errors as zealous lies, La longue marche is worthless...."21 Étiemble's bad faith is evident in the way he quotes her selectively and out of context, his defensive display of his own pedantry through quoting of obscure texts and authors, his rhetorical flourishes, and his nit-picking complaints

octobre 1949 sur la terrasse T'ien an Men; c'était cette révolution passionnée et raisonnable qui avait non seulement délivré de l'exploitation paysans et ouvriers, mais libéré de l'étranger toute la Chine" (La longue marche 8, The Long March 10). The reference is to André Malraux's 1933 novel whose title, meaning "the human condition," is often mistranslated as Man's Fate; it deals in a highly fictionalized manner with an unsuccessful 1927 uprising in Shanghai. (See TCF 212-16, ASD 170-73, for Beauvoir's revised assessment of Malraux, who eventually became quite right-wing, as a dishonest "mythomaniac.")

Ian Birchall's Sartre Against Stalinism makes clear how extraordinarily difficult the French Communist Party made it to be an independent left intellectual; this was even truer in the US. To take only the examples personally closest to Beauvoir, the State Department refused her lover Nelson Algren a passport to come to France; their harassment of Richard Wright and other African-American expatriates is well known.

19 G.F. Hudson, "Mme. de Beauvoir in China," 64.

20 See David Caute, The Fellow-Travelers: Intellectual Friends of Communism, 323-34.

21 René Étiemble, "Simone de Beauvoir, the Concrete Mandarin," 75. 
about her writing style. ${ }^{22}$ It is hard to understand why Elaine Marks chose to include this piece, along with Mary McCarthy's diatribe against L'Amérique au jour le jour 1947, in a 1987 collection presumably intended to increase the interest and attention paid to Beauvoir's work by American scholars. ${ }^{23}$

But it is not hard to understand why Étiemble was literally incoherent with rage: La longue marche attacks him by name, along with David Rousset, Robert Guillain (author of a 1956 polemic against Maoism called The Blue Ants), ${ }^{24}$ and others from the French Right. And Beauvoir doesn't pull any punches. Her quarrel with the Right seems to be unfolding in real time (for instance, she responds to nasty comments French newspapers were making about their trip $)^{25}$ and her rhetorical style, almost from the get-go, makes clear she's in this up to her neck. In a section called "La lutte défensive" (The Defensive Effort), she answers right-wing French attacks on the detention of subversives in China by pointing out that such things go on in France as well, reminding her readers of the Henri Martin affair, and of the recent detention of Claude Bourdet and other journalists who spoke out against the war on Algeria for "demoralization of the nation." 26 (The comparison of Chinese repression to the behavior of the French state seems less incongruous when we remember that at the moment she was writing Algerians and French citizens were being brutally tortured, both in Algeria and on French soil.) She also answers critics who complain that

22 Étiemble especially dislikes her frequent use of the word "concrete," which Beauvoir does use rather insistently, to mark that she is evaluating material gains, not ideological arguments.

23 Elaine Marks, ed., Critical Essays on Simone de Beauvoir.

24 The book's French title was Six cent millions de Chinois, but "les fourmis bleues" became a catchphrase.

25 La longue marche 350, The Long March, 360-61.

26 La longue marche 366, The Long March 378-79. Henri Martin, a French soldier posted to Indochina, was jailed for protesting French attacks on the Viet Minh. Claude Bourdet was a hero of the Résistance who worked with Camus on Combat. His New York Times obituary explains the story: "On a spring dawn in 1956, when Mr. Bourdet was editor of L'Observateur, he was arrested at his home, handcuffed and hauled off to be strip-searched at Fresnes Prison, where the Gestapo had taken him upon his arrest in 1944. The 1956 seizure followed a series of articles in which Mr. Bourdet attacked the French campaign to destroy the guerrillas battling for Algerian independence and condemned plans to call up 100,000 military reservists."

"One hundred thousand young Frenchmen are threatened with being thrown into the "dirty war" of Algeria, with losing the best years of their lives, perhaps with being wounded, indeed killed, for a cause that few among them approve, in a kind of combat that revolts most of them,' he wrote."

"At sundown Mr. Bourdet was released, and in his first post-prison editorial, he observed: 'When somebody rings your bell at 6 A.M. and it is the milkman, you are in a democracy'" (Lawrence Van Gelder, “Claude Bourdet"). 
children in China are "indoctrinated" with the reminder that children are indoctrinated everywhere:

Mme. Rais claimed in Paris-Presse in December 1955 that all children are forced to enroll in the Pioneers, by concerted pressure. Mme. Berliouz shares with us that seeing Pioneers walking in the park brought disquieting images of Nazi youth groups into her mind. These are pure fantasies.... One must have decided in advance that New China is headed by a totalitarian regime to be reminded of the Hitler Youth by seeing Pioneers running up Coal Hill or playing ring-around-a-rosy in the middle of Pei Hai Park. As for the "indoctrination" of the children, they are, certainly, taught to love their country, to want to serve it, to respect the current ethic, and they are educated in the ideology that corresponds to the regime under which they live; and is it not the same in every other country? If Chinese educators are more convincing than their American colleagues, this, it would seem to me, ought rather to be set down to their credit than seen as a liability. ${ }^{27}$

Her Chinese guides take her to see a prison, which she compares favorably to the "model prison" she toured in the US. ${ }^{28}$ And she responds to the outrage of French anticommunists at the idea of Chinese citizens being exhorted to put their country ahead of their family by reminding them that this is also considered an ideal in France, where right-wingers "admire ... those parents who with buttoned lip and uptilted chin smilingly see their sons risk their lives in IndoChina, in Algeria" and where "[t]he entire Right praised the conduct of the

27 “Mme. F. Rais affirmait en décembre 1955 dans Paris-Presse qu'une pression concertée contraint tous les enfants à s'inscrire comme pionniers. Mme. Berlioux nous confie qu'en voyant des pionniers se promener dans les parcs, elle a songé avec inquiétude aux formations de jeunesse nazies. Ce sont de purs rêveries .... Il faut avoir d'avance décidé que le régime de la Chine nouvelle est un totalitarisme pour évoquer les jeunesses hitlériennes en voyant des pionniers danser des rondes au milieu du parc Pei Haï, ou escalader en courant la colline de charbon.

Quant à 'l'endoctrinement' des enfants, certes on leur apprend à aimer leur pays, à vouloir le servir, à respecter la morale en vigueur, et on leur enseigne l'idéologie correspondant au régime dans lequel ils vivent: n'est-ce pas ce qu'on fait partout? Si les éducateurs chinois sont plus convaincants que leurs collègues américains il me semble que le fait doit plutôt être porté à leur crédit qu'inscrit à leur passif" (La longue marche 154-55, The Long March 159. Translation modified.).

28 La longue marche 372-73, The Long March 384-85. Readers of L'Amérique au jour le jour 1947 will recall that on that occasion she was shown, and appalled by, the electric chair. 
Francoist general who let his son be shot rather than surrender the Alcazar."29 The battle lines are very clearly drawn, and Beauvoir's ire at these (now forgotten) writers echoes the denunciations of French bourgeois hypocrisy we've seen in her work as early as Pour une morale de l'ambiguïté.

Still, some of what Étiemble says is not wrong. In hindsight one can only blush to read that "the power [Mao] exercises is no more dictatorial than that of, for example, Roosevelt." ${ }^{30}$ Beauvoir took at face value the claims that there were no political prisoners and no police state, that all was going well in Tibet, that trials were conducted fairly, that unlike in Stalinist Russia "no citizen in China is bothered on account of his opinions." ${ }^{31}$ On this last point David Caute observed in 1988, "out of such declarations are the tablets of folly compiled." 32 As I said, I am not arguing that this is a good book. But it has been caught within, and distorted by, two different "grand narratives" about the twentieth century in ways that mask what was and is valuable about it. The story of Beauvoir's trip is the story of an honest failure, and a more interesting failure than an Étiemble, or a Markowitz, can let themselves see.

The fact is, events overtook La longue marche even as she was writing it. Her visit to China occurred before the most disastrous agricultural reforms, and even a critic as malevolent as G.F. Hudson admits that

[i]n one respect Madame de Beauvoir is deserving of sympathy; her sojourn in China was in $1955^{-56}$, when the trend was toward a relaxation of the regime, and much of what she has written in defense of it (especially about the position of the Chinese intellectuals under Communism) has already been refuted by the intensified repression since the end of the "Hundred Flowers" experiment in the middle of 1957.

29 "En France on a toujours tenu pour hautement morale la subordination des sentiments familiaux à de nobles entreprises, et tout spécialement à la guerre. On admire que des parents acceptent avec le sourire de voir leurs fils risquer leur peau en Indochine, en Algérie.... [Note] Toute la droite a exalté la conduite du général franquiste qui laissa fusiller son fils plutôt que de rendre l'Alcazar" (La longue marche 156, The Long March 160-61).

$30 \quad$ "[L]e pouvoir qu'il exerce n'est pas plus dictatorial que celui qu'a détenu par exemple un Roosevelt" (La Longue marche 414, The Long March 427). To be fair, she was probably thinking of the control of American economic and cultural life Roosevelt and the US central government did, in fact, take on during the Second World War, that is, under emergency conditions.

31 “Aucun citoyen en Chine n'est inquiété pour ses 'opinions'” (La longue marche 366, The Long March 378).

32 Caute, The Fellow-Travelers, 347. See also Paul Hollander, Political Pilgrims: Travels of Western Intellectuals to the Soviet Union, China, and Cuba, and Simon Leys, Essais sur la Chine. 
But he continues:

However, although she pays lip service to the proposition that "China must become more liberal," there is little ground in this book for supposing that Madame de Beauvoir would be upset by any degree of coercion which appeared to be required for the maintenance of Communist rule in China. ${ }^{33}$

And that point is not right: as Sandrine Dauphin points out, when the time came, Beauvoir would be quite critical, as she and Sartre were of Castro once the "honeymoon of the revolution" there was over. ${ }^{34}$ In 1971, as part of a roundup of the world political situation, and directly following the explanation I quoted above for how and why Fanon's hopes for Algeria had been disappointed, she'd write,

And what is happening in China? That is a question I really should like to be able to answer. I went there in 1955 and when I came back I wrote a book about it. Since then I have learnt all I could about the period of "the hundred flowers," the great leap forward, and the experiment of the communes. Whereas the USSR advanced a model of a wealthy socialism and preached patience to the under-developed countries, China put forward a model of a poor socialism and encouraged the oppressed nations to violent action; and our sympathies went to China.... But when the Cultural

33 Hudson, "Mme. de Beauvoir in China," 66.

34 Beauvoir's honest documentation of shifts in her thinking, consonant with the general principle that one's political views can (and ethically should) change as situations develop and as one learns more, was described at the Diverse Lineages of Existentialism conference by Ofelia Schutte (for the case of Cuba) and by Robert Bernasconi (with respect to the US). Dauphin writes: "Nevertheless, when the moment came, Beauvoir and Sartre would criticize Castro and Mao.... To be sure, when the maoist editors of the French journal La Cause du Peuple were arrested in 1970, Jean-Paul Sartre assumed the role of responsible editor. But what led to his support was freedom of the press and sympathy for the younger generation, more than genuine support for maoist thinking." [D'ailleurs Beauvoir et Sartre sauront critiquer le moment venu Mao et Castro .... Lorsque nombre d'intellectuels se proclameront maoïstes, ils préserveront une certaine distance. Certes, lorsque les directeurs maoïstes de la revue La Cause du Peuple sont arrêtés en 1970, JeanPaul Sartre assumera la direction de la revue. Mais ce qui le conduira à ce soutien, c'est davantage la liberté de la presse et sa sympathie envers les jeunes qu'un réel soutien à la pensée maoïste (Dauphin, "En terre d'Icarie," 120).]

See also Richard Wolin, The Wind from the East: French Intellectuals, the Cultural Revolution, and the Legacy of the 1960 . 
Revolution broke out, no one could give us a convincing explanation of the reality that underlay the words. ${ }^{35}$

At that stage she feels unable to fully credit either the frightening and contradictory stories appearing in the rightist press, or the propaganda emanating from the Chinese regime, or the conjectures from outside "China experts." ${ }^{36}$ Two friends, Kateb Yacine and Alejo Carpentier ("le grand écrivain cubain") bring back disquieting eyewitness reports that images of Mao are everywhere and obligatory, that his Little Red Book seems to be the only book for sale, that loudspeakers are broadcasting its words and taxi-drivers and air hostesses repeating them mechanically, over and over.... Carpentier tells of seeing an "exemplary worker," a gatherer of dung, brought to the University to lecture to the professors. ${ }^{37} \mathrm{~A}$ formal visit by Beauvoir and Sartre to the Chinese embassy in Paris leaves her "none the wiser."38 By 1970 she feels better informed, and able to account for what she has heard: for instance, the dung-gatherer's lecture to the professors can be understood as "part of a great campaign to re-establish manual labor in the public esteem and to do away with the excessive prestige of intellectual work." Mao's idea of "continuous revolution" to prevent the hardening of bureaucracy makes sense to her. ${ }^{39}$ But she disclaims any "blind confidence" and retains her right to judge, for instance with respect to the Little Red Book's "depressingly platitudinous elementary truths," ${ }^{40}$ and the "dogmatic naïvety" of publications directed at the West.

When I am told that the workers have a right to three weeks of holiday but that they give them up because of their socialist enthusiasm, what stays in my mind is the fact that they do not take holidays: enthusiasm

35 "Et que se passe-t-il en Chine? Voilà une question à laquelle je voudrais bien pouvoir répondre. J'y ai voyagé en 1955 et à mon retour, je lui ai consacré un livre. Par la suite, je me suis renseignée le mieux possible sur la 'période des cent fleurs', le grand bond en avant, l'expérience des communes. Tandis que l'URSS proposait un modèle de socialisme riche et prêchait la patience aux pays sous-développés, la Chine proposait un modèle de socialisme pauvre et encourageait les peuples opprimés à des actions violentes: c'est à elle qu'allaient nos sympathies. J'ai dit qu'à Helsinki, Sartre avait soutenu ses vues. Mais lorsque a éclaté la révolution culturelle, personne n’a pu nous expliquer de façon convaincante quelle réalité recouvraient ces mots" (TCF 562-63, ASD 443).

36 TCF 563, ASD $443-44$.

37 TCF $563-65, A S D$ 444-45.

38 TCF $565^{-66, A S D} 445^{-46 .}$

39 "On le comprend à présent: cet épisode faisait partie d'une vaste campagne pour réhabiliter le travail manuel et refuser de surestimer le travail intellectuel" (TCF $564, A S D 445 \mathrm{n}$ ). "[V]érités premières d'une décourageante platitude" (TCF 565, ASD 445). 
cannot be institutionalized.... Saying that China is a paradise is all the more absurd since the revolution has not yet been carried through, as Mao himself admits. But there is no need to make a myth of China in order to feel great sympathy for the country. ${ }^{41}$

As times change, one does the best one can to continue informing oneself, which may lead to a change in view. But is this really a reversal? She had already said, in the conclusion to La longue marche, "It is an error to judge China as though things were stopped."

I have understood that, more so in China than anywhere else, there is one mistake you have to avoid: judging things as though they were final, fixed as such. In this country which is ceaselessly on the move, the present derives its meaning from the past it is leaving behind [qu'il dépasse], from the future it is ushering in.

To denigrate the regime because the standard of living there is still low or because capitalism yet subsists is to be unmindful of China's situation: you need a place to stand if you are going to move the world, to transform China you must use the past as fulcrum and lever. But what aggravates me most is this shiny ready-made benevolence which permits certain travelers to extol as absolute those achievements which only make sense as stepping stones to something else. It is not true that a Chinese village is more comfortable and richer than a village in France; what is extraordinary about it is the progress it represents over the villages of the past. It is likewise untrue that the Chinese woman is generally the most emancipated in the world. It is naïve to be overawed by the fact that the Archbishop of Peking openly approves of the regime; if he didn't he'd lose his

41 "Empêcher une nouvelle classe privilégiée de se former, donner aux masses un authentique pouvoir, faire de tout individu un homme complet:je ne peux que me rallier à un tel programme. Cependant, je ne saurais accorder à la Chine cette confiance aveugle que jadis l'URSS a suscité dans tant de cœurs. La propagande des revues qu'elle destine à l'Occident me consterne par sa naïveté dogmatique. Si on me dit que les ouvriers ont droit à trois semaines de congé mais qu'ils en font sacrifice par enthousiasme socialiste, ce que je retiens c'est qu'ils ne prennent pas de congé: l'enthousiasme ne s'institutionnalise pas. Prétendre voir dans la Chine un paradis est d'autant plus absurde que, de l'aveu même de Mao, la révolution n'y est pas achevée. Mais il n'est pas besoin d'en faire un mythe pour se tourner vers elle avec sympathie" (TCF $568, A S D 447-48$ ). Her comment that one need not make a "myth" of China dovetails with Wolin's less sympathetic account of what "les maos" were up to; unlike Beauvoir herself, they made no distinction between Mao's original revolution, and the upheavals of the late 1960s and early 1970s, or indeed between "les mythes et les faits." But we should bear in mind too Beauvoir's awareness that myths were no less powerful because of not being true. 
miter tomorrow. This rapturous enthusiasm offends me not only through the errors it leads to but because China deserves to be seen for what it is: you will sell its efforts short if you do not recognize the difficulties they involve. I very much fear that these perfervid bearers of good tidings with their travel diaries all but written up in advance will have trouble convincing the folks back home. It is a pity. This moment in Chinese history is stirring precisely because of the as yet incomplete character of the victories it has won, because of the immensity of the obstacles it has still to subdue and the toughness of the struggle it is engaged in. ${ }^{42}$

This is one of the few passages Étiemble cites with approval, while regretting that Beauvoir did not follow through on its insight. But as I said many pages ago about Spelman and Deutscher, which of these utterances gets to stand as "Beauvoir"? One may pick and choose in good faith, or otherwise. Overall, Beauvoir's relationship to China was and remained a dynamic engagement with a changing society, a materially-based engagement with China which changed in response to historical changes initiated there.

\section{$2 \quad$ Reality-Testing and Cold War Frames}

When I first started working through La longue marche, my idea was to find out "what really happened" and compare what Beauvoir said with "what we now know." I was looking for an objective set of benchmarks: what could she

42 'J'ai compris qu'en Chine, plus que partout, il y a une erreur à éviter: c'est de juger les choses comme si elles étaient arrêtées. Dans ce pays qui ne cesse de bouger, le présent tire son sens du passé qu'il dépasse, de l'avenir qu'il annonce. Dénigrer le régime sous prétexte que le niveau de vie y est encore bas, ou parce que le capitalisme y subsiste, c'est méconnaitre sa situation: on ne peut transformer la Chine qu'à partir de ce qu'elle était. Mais je suis surtout agacée par cette bienveillance a priori qui amène certains voyageurs à admirer dans l'absolu des réalisations qui n'ont de sens que prises dans leur devenir. Il est faux qu'un village chinois soit plus confortable et plus riche qu'un village français: ce qui est remarquable, c'est le progrès qu'il constitue par rapport à ceux d'autrefois. Il est faux que la femme chinoise soit en général la plus émancipée du monde. Il est naïf de s'émerveiller parce que l'archevêque de Pékin approuve ouvertement le régime: s'il s'y opposait, il ne serait plus archevêque. Cet enthousiasme me choque non seulement par les erreurs qu'il entraîne, mais parce que la Chine mérite d'être reconnue dans sa vérité; c'est mésestimer ses efforts que de ne pas en voir les difficultés. Je redoute que la propagande de ces zélateurs ne se retourne contre eux: il sera trop clair que leur siège était fait d'avance. C'est dommage. Ce moment de l'histoire chinoise est émouvant justement par le caractère encore inachevé des victoires remportées, par la grandeur des obstacles à vaincre et la dureté de la lutte entreprise" (La longue marche 405-6, The Long March 419, translation modified, emphasis in original). 
plausibly have seen or known, how might we read her book apart from the Cold War context of its writing and reception. I was unprepared for the continued absence of scholarly consensus about this period of Chinese history, the enduring reach of incompatible frames with roots in diverging political commitments, some dating from the Cold War itself and other from the 196os. Even basic facts, such as how many people perished during which eras, and how much can be blamed on famine or flood versus how much can be attributed to Communism, continue to be bitterly disputed among scholars. I must leave such matters to be debated by others. What I can say, though, is that the written authorities Beauvoir turned to after her return, to fill out the gaps in her information, appear still to be reputable authorities today; her research strategy seems to have been a sound one. For instance, in her discussion of the peasants, she relies heavily on a 1925 book called Country Life in China by an American researcher named Daniel Harrison Kulp, who arrived in the 1920 on the coast of southern China, where he conducted anthropological and sociological fieldwork. I found a 2005 article by one Zhou Daming who wrote his dissertation by going back to the same village, and basically concluded that Kulp's conclusions were sound and can still stand, since he observed cultural continuities that had been interrupted from 1949 to the 1970s. Zhou describes Kulp's concept of "familialism" as an influential, and still correct, foundation concept.

As in The Second Sex, Beauvoir draws on fictional works, such as Ding Ling's Le soleil brille sur la rivière Sang kan and especially Ba Jin's The Family, to flesh out her understanding of how living in China felt from the inside to those most directly involved. She also gives a lot of credence to the work of Pearl S. Buck: I was brought up to sniff at Buck as a sort of Book-of the-Month Club middlebrow, but well-respected China scholar Charles W. Hayford, writing in 1998, regards her as a good, unbiased source of information. ${ }^{43}$ Some of the most compelling sections of La longue marche describe urban poverty and exploitation, particularly in Shanghai, in the years before the Revolution: this she did not see, but it was described to her vividly by Rewi Alley and others, and she corroborated what they told her by reading in sources that appear to still be valued by both Chinese and non-Chinese writers. The question of whether the average person was actually better off after the revolution, or not, does not appear to be one I can settle. However, what I can say is that this was the main, if

43 Daniel Harrison Kulp, Country Life in South China: The Sociology of Familialism; Zhou Daming, "Follow-up Investigations in Phoenix Village"; Charles Hayford, "What's So Bad About The Good Earth?" See also Xiaorong Han, Chinese Discourses on the Peasant, 1900-1949. 
not the only, question, in which Beauvoir was interested; it appeared to weigh more heavily for her and her companions than questions which affected intellectuals more directly and narrowly, such as the future direction of literature and the arts.

I must say I did not expect the extraordinary vindictiveness with which some commentators continue to settle scores from the Cold War. I had high hopes when I saw that Anne-Marie Brady's Making the Foreign Serve China: Managing Foreigners in the People's Republic, from 2003, included a discussion of Beauvoir. Brady made use of newly opened archives to trace the historical development of waishi, short for waijiao shiwu (diplomatic matters)-for instance the training received by the cadres and interpreters, and ordinary citizens who were instructed to smile at visitors. But Brady's book is absolutely cynical, and in viewing all attempts at cross-cultural "friendship" as Machiavellian manipulations she badly overstates her case. The sections on Beauvoir are a terrible misrepresentation: relying on the notoriously inaccurate biography by Deirdre Bair, Brady claims that Beauvoir was deliberately lying, painting a rosy picture of her China trip in La longue marche while sending the "truth"that she found China "drab and boring," for instance - in letters to her American lover, Nelson Algren. In fact the phrase "drab and boring" appears nowhere in the (readily available) letters; most of what Beauvoir wrote to Algren about China is quite positive, and tracks accurately with what La longue marche has to say about the difficulties of "official tourism" and the reasons why she was nonetheless enthusiastic about the hope Mao was bringing to his people. ${ }^{44}$

Brady is especially nasty about Beauvoir's relationship with one of her interpreters, the writer Chen Xuezhao, who is referred to in La longue marche as "Madame Cheng." Brady quotes Beauvoir's own enthusiastic description:

Never a word of nonsense or propaganda from her lips; she is so firmly convinced of the benefits conferred by the regime and its necessity that she has no need to tell fibs to herself or anyone else; independent, spontaneous, fond of laughing and fonder yet of talking, she knows nothing of self-censorship: witty, tranquil, her frankness in great measure made up for the inflexibility of most of the cadres I had dealings with. ${ }^{45}$

But, Brady claims, this account is falsified by Chen's own memoirs:

44 A Transatlantic Love Affair: Letters to Nelson Algren, 517-18.

45 Anne-Marie Brady, Making the Foreign Serve China: Managing Foreigners in the People's Republic, 95 . 
What De Beauvoir described as Chen's "frankness" and "spontaneity" was officially sanctioned by "the leadership," who allowed her to speak directly to the philosophers, rather than through the interpreter who accompanied them at all times. As planned, this resulted in the pair finding her more "believable" than others they spoke to. ${ }^{46}$

However, one volume of Chen's memoirs has been published in English under the title Surviving the Storm, and so I have been able to read it myself. I came away with a very different impression. It is true that Chen's encounter with Beauvoir was much less important to Chen than it was to Beauvoir. But it seems unlikely that Chen's sentiments of support for Mao were forced or feigned, since she was still saying much the same thing when she wrote the memoir in 1979, by which time she had suffered terribly, first in the anti-Rightist campaign, and then during the Cultural Revolution. Chen continues to talk, as she did to Beauvoir, about wanting to correct her faults as a bourgeois writer, to be more oriented to the people. ${ }^{47}$ (I gather something similar is true of Ding Ling. $)^{48}$

Like so much of this anti-Communist literature, with its talk of "brainwashing," Brady's work appears to subscribe to an extremely over-simplified picture of human subjectivity, as though people had a two-way switch in their heads labelled either "sincere" versus "fake," "society" versus "self." 49 It is undoubtedly

$46 \quad$ Ibid., 95 .

47 Surviving the Storm was written during the period of so-called "scar literature," when frank and critical accounts of the Mao period appeared as part of a reckoning with the upheavals of the Cultural Revolution. Despite her suffering (she was barred from Party membership, forbidden to publish, assigned to menial tasks, abused verbally and physically), Chen seems never to have rethought her strong desire to "go to the countryside," her insistence on working directly with rural peasants rather than urban intellectuals; quite late in the book she observes rather acidly that if she had wanted wealth and fame she would never have gone to Yan'an (loc. 2126 - she joined Mao there in 1940, and was among his earliest supporters). About the encounter with Beauvoir and Sartre, she says, "an interpreter accompanied us, but the leadership said I could speak to them directly." Chen Xuezhao, Surviving the Storm: A Memoir, loc. 945.

48 As described by Tani Barlow in her introduction to the selected writing of Ding Ling, $I$ Myself Am a Woman, and in chapter 5 of The Question of Women in Chinese Feminism.

49 Even Simon Leys's debunking essays have uneasy moments where it is clear that some of the official spokespeople might actually have been as enthusiastic as they presented themselves as being. How would we know? Did they even know? See also Zhong et al., Some of Us, and Orville Schell, Watch Out for the Foreign Guests! China Encounters the West. Saba Mahmood's discussion of the complexities of developing subjectivities might be apposite here. A similar issue about subjectivity is the theme of Beauvoir's own late novel, Les belles images, set in Paris: Laurence, an advertising copywriter, wrestles with 
true that there were many things Chen did not feel able or free to say to Beauvoir. But we should not be too hasty to assume that we know what they would have been, or to see the choices the Chinese woman would have made about this as externally imposed. That would be a very poor model indeed for intercultural feminism.

What emerges from my own reading of Surviving the Storm is a highly sympathetic figure, and exactly the right person to have introduced Beauvoir to China. For one thing, her French was excellent - she had lived in France from 1927-35, during which time she studied with Marcel Granet. ${ }^{50}$ But beyond this, there are striking parallels between the two women's lives that must indeed have made for conversation. Almost exact contemporaries, both were intellectual prodigies who felt stifled in traditional families; their early lives were marked by romantic rebellion and non-conformity, by the fear of turning into one's mother and the determination to earn one's own living. One big difference between them was that Chen found feminism, as an explicit set of ideas, at an early age, as a member of the New Culture movement. ${ }^{51}$ Beauvoir had to wait a lot longer. In China, feminism and modernity were inextricably linked in the eyes of even the most prominent male modernists, whereas in 1920s France and England the response of high male modernism to the "woman question" had been at best ambivalent, and sometimes openly hostile. ${ }^{52}$ Beauvoir is also not wrong to see that Chen had explored and was exploring some of the same desires, temptations, fears, moral issues that she and Sartre were confronting after the Second World War: a retrospective disgust with one's earlier individualist position, an understanding that one's earlier "rebellions" had been underwritten by class privilege, and a determined commitment to write differently in future. Chen is in no way exoticized or patronized as an "informant"; Beauvoir treats her, and the other French-speaking Chinese intellectuals she meets, in the way she treated Richard Wright and Nelson Algren on her first trip to

the difficulty of separating her own voice from consumer culture's incessant incitements to desire, even in the confines of her own private mind.

5o This is the same Marcel Granet quoted in the introduction to The Second Sex.

$5^{1}$ In the 1920 and 1930 s she became a valued colleague and friend of well-known writers $\mathrm{Lu}$ Xun, Mao Dun, and Qiu Qiubai; her prose poems and personal essays were popular with young readers who were seeking vernacular alternatives to traditional Chinese culture. In 1923 one of her first pieces, "The New Woman I Hope to Be," won second prize in an essay contest sponsored by the Shanghai Shibao. According to Jeffrey Kinkley, it "argued for equality between the sexes, insisting that Chinese women, like [Ibsen's] Nora, must be able to stand on their own two feet economically rather than depend on men" (loc. 134).

$5^{2}$ One might remember for instance, the surrealists' mingled fascination and horror at the female body, or what happened to the feminist little magazine The New Freewoman when Ezra Pound took it over and renamed it The Egoist. 
America. Again this seems to have been less a "working on" than a "working with."

I want to point to two particular moments of contact between them in $\mathrm{La}$ longue marche which strike me as, for lack of a better term, authentic. Chen explains that even though the marriage law of 1950 and the opportunity for women to earn their own living have liberated women in theory, many women continue to pursue marriage as their primary aim: "They have always been viewed as merchandise,' Mme. Cheng said to me. 'Well, today they're viewing themselves as merchandise."'53 $\mathrm{A}$ bit later, the two women are at the opera: "On the stage a young heroine was desperately struggling in an emperor's lewd embrace. 'That's why Chinese women wanted the Revolution,' Mme. Cheng said ardently, 'in order to have the right to say no to that kind of thing."'54 Now, Beauvoir's denunciation of arranged marriage in La longue marche is uncompromising. Before we sneer at this as an example of Western bias, we could remember the many pages she devotes in The Second Sex to denouncing arranged marriage in France. ${ }^{55}$ In La longue marche, while explaining why Mao's new family code of 1950 - which did away with child marriage, infanticide, and concubinage, required the formal consent of both partners to any marriage, made divorce available to women as well as men and allowed widows to remarry - in practice had a hard time gaining acceptance, she explains that as a general rule the pace of cultural change is slower than written law can enforce: "Even in France common custom is, on this point, less enlightened than the law; matches are still arranged and some marriages are pure business deals." 56

53 ' 'On les a toujours traitées comme des marchandises,' me dit Mme. Cheng, 'alors, maintenant, elles se traitent elles-mêmes comme une marchandise"' (La longue marche 144, The Long March 149).

54 “J'ai été frappée par une réaction de Mme. Cheng, assistant à côté de moi à un opéra où se déroulait une scène de viol; la jeune héroïne se défendait éperdument contre les entreprises d'un empereur lubrique. 'Voilà pourquoi les femmes chinoises ont voulu la révolution,' me dit-elle avec feu: 'pour avoir le droit de ne pas aimer'" (La longue marche 149, The Long March 154). The translator omits "une scène de viol," a rape scene.

55 We could also remember that she herself was the product of an arranged marriage, and saw some of its sadder results in the life of her mother. Indeed, in Mémoires d'une jeune fille rangée she attributes Zaza's death to the intolerable psychological pressures of the bourgeois marriage system, pressures she herself escaped only because her father's financial ruin left him unable to offer a dowry.

$5^{6}$ "Même en France, les mœurs sont sur ce point à la remorque du code; il existe encore des unions arrangées et certaines sont de véritables marchés" (La longue marche 139, The Long March 144). Lisa Greenwald's recent chronicle of feminist activism in France reminds me that 'ffamilialism,' an obsessive focus on the family as the backbone of society and the countervailing force to the general loss of morals and depopulation, was the official doctrine of Vichy," and an important target of French feminist activism in the years 
To turn back to the dismissive footnote in The Second Sex that has so exercised Markowitz and others: the Chinese history that The Second Sex omits is given very fully in La longue marche, and in a very similar manner to the history chapters of that earlier work.$^{57}$ Attention is paid, not just to oppression, but to expressions of resistance-literary texts of all periods are mined for examples of both-and Beauvoir also carefully details such matters as changes to the family code and inheritance laws. However, I suspect her discussion of "familialism" and "feudalism" would still not satisfy Markowitz. The case of Chinese women provides Beauvoir with an even stronger illustration of her argument in The Second Sex that the history of women is inexorably linked to developments in the history of private property. ${ }^{58}$ The story she tells is indeed an evolutionary story; however, it is a story of economic development (and social developments that follow from economic causes); it has nothing to do with race. This is not Darwin or Spencer, or even really Hegel; it is still, for better or for worse, Engels. ${ }^{59}$ The same syncretic or synoptic cross-cultural gaze we saw in her earlier work is applied here, but from the other way around. And the conclusion she draws from her discussion of Mao's marriage law is the same conclusion she drew in The Second Sex: women's economic autonomy is an absolutely necessary condition for women's liberation, but not a sufficient one. ${ }^{60}$

that followed. Greenwald, Daughters of 1968: Redefining French Feminism and the Women's Liberation Movement, 27.

$57 \quad$ La longue marche 123-59, The Long March 127-64.

58 "In every civilization the history of women's rights is directly linked to the history of inheritance [footnote: As I tried to show in The Second Sex] which has evolved as a dependent variable of the changing economic and social context. In China, however, what with the monolithic permanence of family structure from the beginning of recorded history down to the twentieth century, the right of succession did not alter." [Dans toutes les civilisations, l'histoire des droits de la femme se confond avec l'histoire de l'héritage. ([Note] J'ai essayé de le montrer dans Le deuxième sexe), qui a évolué en fonction de l'ensemble des transformations économiques et sociales. Or en Chine, étant donné la permanence de la structure familiale, depuis le début des temps historiques jusqu'au $\mathrm{Xx}^{\mathrm{e}}$ siècle le droit de succession n'a pas varié (La longue marche 126, The Long March 130).]

59 In fact, several central positions taken in The Second Sex - that women will only be liberated by finding meaningful work to do, that the interests of women are not fully served by an individualist approach to "happiness" - are pretty close to what Mao said in the Yenan declaration, which need not imply "influence" in either direction. As I said several hundred pages ago, if an idea is a good one, more than one person will have it.

6o Another similarity is that here, too, women are understood as among the greatest enforcers of traditional views that are oppressive to (other) women, and indirectly to all women including themselves: see Beauvoir's discussion of the role played by mothers-in-law in 
But Markowitz does not mention Beauvoir's 1957 repair of her 1948 omission, and seems generally uninterested in the book's historical dimension. ${ }^{61}$ After briefly noting La longue marche's materialist approach, she writes: "But Orientalism is a hardy plant, and The Long March is, alas, itself peppered with a variety of Orientalist tropes: those of the Oriental despot, the absence of Chinese history, the effeminate Chinese male, and the Chinese lack of energy and personality." A footnote follows: "For tropes on history in The Long March, see $35^{-36}$ and 88; on sensuality and lack of personality, see $64-65$; on sex and gender disorder, see 152-54 and 478; on backwardness in science and technology, see 203-4 and 363; and on the pre-Communist Chinese failure to be truly human, see $484 . " 62$ Much of this is misleading: for instance, rather than "effeminacy" and "gender disorder," Beauvoir is actually discussing a lack of jealousy and competition shown by male university students toward their female counterparts, something she found surprisingly different from the Sorbonne, and rather refreshing. Markowitz seems again to have proceeded by generating a list of isolated "problematic" sentences, most of which she distorts by taking them out of context.

"Tropes" are, of course, an important key to a writer's underlying (conscious or unconscious) view. But are they more important than what the writer is arguing, and more important than the explicit analysis and empirical examples adduced to support that argument? (Can a "trope" even be said to have meaning, when detached from the argument or narrative on whose ground it arises?) Again, it feels a bit unfair to lean so heavily on Markowitz, since scholarship-by-search-and-replace is hardly unusual now: within the current consensus about feminist method, policing the texts of the past for things "we wouldn't say today" is standard operating procedure. But perhaps that methodological consensus itself is not beyond debate. ${ }^{63}$

However, I do not want to sugarcoat the extent to which La longue marche fails the current litmus tests of multiculturalism. Beauvoir shows no respect whatsoever for Chinese tradition; her discussion of ancient China is often dismissive, and she gets things wrong. She does not like the literati, calling them

maintaining the cruelties of the "familial system," in particular La longue marche 141, The Long March 135.

61 Despite the charge with which she opens her article, that scholars who overlook Beauvoir's "orientalism" are being ahistorical, she herself fails to note that the Long March is concerned not with "China" but with Mao's revolution.

62 Markowitz, "Occidental Dreams," 280-81.

63 Critique is, of course, indispensable; but a "search and destroy" attitude toward "tropes" can actually impede genuine critique, which needs to engage with what earlier writers are actually arguing. 
an elite culture, a court culture. She finds Chinese monuments ugly and uninteresting, designed for empires and not for people; she thinks the Forbidden City goes on and on and resembles itself, she's particularly unimpressed by the ceramics; ${ }^{64}$ what she says about Chinese painting, and its failure to develop, is quite cringe-making. She does confirm the value of Chinese medicine, which she says Chiang Kai-Shek had outlawed, ${ }^{65}$ but she describes Chinese religion as superstition and magic. 66

Confucianism and Taoism (of which she gives a somewhat confused historical account) are seen as stagnant, as having an "immanent rather than a transcendent ontology." ${ }^{\prime 7}$ As descriptive terms, scholars of religion might actually not disagree with that last point, but as an existentialist, Beauvoir has to argue that transcendence is better, and she does. She takes Chinese ideas seriously as ideas, as philosophy, and argues against them, pitting Kant against Confucius, for instance, because Kant's individual is universal whereas Confucius's individual operates within a hierarchy where he must observe his place. A value judgment is clearly present in the critique of Taoist quietism and a Confucianist conformism as "bureaucratic" (du fonctionnaire). It is not however a question of the "sleepy East" vs the triumphant West, but rather a philosophical difference, argued philosophically. A view of the relation between subject and world as immanent rather than transcendent, as harmonious and unchanging, is deeply uncongenial to the existential framework of always trying to see the present in terms of the future project, of "devenir": we've seen this framework since Pour une morale de l'ambiguité, and Beauvoir applies it consistently when she says, "it is an error to judge China as though things were stopped."68 Moreover, the existentialist framework dovetails seamlessly with a worldview based, not in race, but in political economy: a cyclic, or non-linear, conception of time, such as she sees in Chinese philosophy, cannot provide a resource for modernization. ${ }^{69}$

$64 \quad$ La longue marche 58-63, The Long March 62-7.

65 La longue marche 345-49, The Long March 355-6o.

66 La longue marche 84, 222-35, The Long March 88, 228-42.

67 La longue marche 253-62, The Long March 260-71.

68 We might also bear in mind that when Beauvoir spoke against superstition, and in favor of the Enlightenment, it was as an ex-Catholic who had modernized herself by leaving God behind, against significant opposition from her own original social milieu.

69 In an odd twist, this point was anticipated by Lorraine Hansberry, as an aside in her enthusiastic leftist reading of The Second Sex: "[T] oday American journalists try to find a desperate amusement or frivolity in the fact of the liberation of the women of China from the most barbaric forms of their former oppression. They cannot see that, suspending the liability to 'Communist sympathy' for a moment, a nation in fertile birth, or a renaissance, be it young America or ancient China, cannot afford the traditional misuse, and therefore 
Should we produce an object called orientalism and say that this is that? Well, which orientalism would it then be? If one situates Beauvoir (as Markowitz does not do) within the history of French orientalist writing, which is indeed a shameful one, one can see that hers is not, for instance, the orientalism of a Pierre Loti. Loti arrived with the mopping-up army after the Boxer Rebellion and wrote in The Last Days of Peking about "an intolerable smell of the yellow race, impossible to define"; he describes his delight in rolling about in the Empress's bed after the sack of her palace. ${ }^{70}$ This is not that. Nor is it the attitude, which Richard Wolin describes as "sinophilia," taken in the 196os and 1970 s by the group around the journal Tel Quel, especially Philippe Sollers and Julia Kristeva, whose quasi-feminist 1974 book Des Chinoises makes an essentialist romance of the inscrutable Chinese countenance. As Wolin writes, "China for them was a trope"; while some good developments came out of French "Maoism," particularly for Foucault, the arrogance of that encounter remains breathtaking, and a bit too close for comfort to the sinophiles of a previous generation, as Spivak shows. ${ }^{71}$

virtual uselessness of half its people. The frontier demands work, hard work, and a dedication to the future. There is not the time to clutter it with the worthlessness of the uselessness of women. Nothing could better indicate the artificial nature of their oppression to begin with. If the Communists of China have indeed ideologically elevated woman to a place of dignity which is beyond her mere economic status, this is hardly a point of jest, but one of the more inspiring developments of modern history" (Hansberry, "An American Commentary," 136-37).

$70 \quad$ "[U]ne intolérable odeur de race jaune qui ne se peut définir" (Loti, Les derniers jours de Pékin, 150).

71 Richard Wolin, The Wind from the East, 20 and 114. For Wolin, "French Maoism operated at a dangerous remove from the reality principle. Mao's China becomes a projection-a Rorschach test—for the students' overheated revolutionary fantasies" (122). "[T]he role that bourgeois self-hatred played in their pro-Chinese worldview was inestimable" (137). See also David Macey, "Rebellion, or, Analysis," and Eric Hayot, Chinese Dreams: Pound, Brecht, Tel Quel. On Kristeva specifically, see Spivak, "French Feminism in an International Frame," and Lisa Lowe, Critical Terrain: British and French Orientalisms, 136-52.

Wolin's portrait of the Tel Quel group as opportunists is not falsified by Kristeva's own account in her autobiographical novel, Les samouraï. The whole episode reminds me of Beauvoir's remark about the Partisan Review boys: "They would burn down the whole world to save their stupid rag of a magazine" (Lettres à Sartre, 296). Beauvoir's own view of the Cultural Revolution was considerably less romantic, as we saw above. And in explaining the support she and Sartre offered to the group of young activists around the journal La Cause $d u$ Peuple, she'd say that she sympathized with "les maos" "despite my reservations-especially, my lack of blind faith in Mao's China” (ASD 478). [Malgré quelques réserves-en particulier je ne saurais avoir une foi aveugle dans la Chine de Mao-je sympathise avec les Maoistes (TCF 607)]. 
In sharp contrast, when Beauvoir celebrates the sweeping away of decadent Chinese customs in favor of a cleaner and more equitable modernity, she is echoing, not French orientalists, but the Chinese writers of the May Fourth movement, whose influence was still very palpable among Chinese government leaders in 1955. This was especially true of Mao Dun, with whom she records some long conversations. Beauvoir frequently quotes and cites "the intellectuals of the May Fourth movement," particularly in her chapters on "Culture" and "The Family," and she has clearly studied their works in detail. ${ }^{72}$ Beauvoir's most "Hegelian" statements about "progress" and evolution are connected directly to ideas of modernity and modernization expressed by Chinese revolutionaries; every one of the "orientalist tropes" Markowitz scolds in Beauvoir's text can be traced to that generation, especially to the feminists (male and female) who were an integral part of the movement, and of its (very significant) legacy to Mao and those around him. ${ }^{73}$ What Beauvoir has to say about the backward or "static" nature of Chinese culture is actually quite mild compared to what Lu Xun, Hu Shi, Jin Tianhe, and He Jin had to say. ${ }^{74}$ And while the term "feudalism," as shorthand for what must be left behind, now echoes quite oddly in our (Western) ears, it is not just orthodox Mao, but part of a discourse pursued by nearly all intellectuals in China before 1949. These writers didn't always agree about the extent to which China was still feudal, or about how best to address the problem, but they did agree that "feudalism," "familialism," and the long-traditional subjection of women were harmful, not just to women themselves, but to all of China.

72 She sent Nelson Algren a book by Lu Xun which she thought he would like: this was in keeping with the idea they shared of an international left-intellectual writing practice (see Altman, "Simone de Beauvoir as Literary Writer"). She also sent him some Chinese "trinkets," despite saying in La longue marche that if she really wanted to bring back "typical objects" as souvenirs, she'd choose a spittoon and a thermos bottle of tea (La longue marche 418, The Long March 431-32).

73 For an account of Mao's early writing in favor of women's emancipation, see Delia Davin, "Gendered Mao: Mao, Maoism, and Women." "Notable also are ten passionate pieces written in response to the suicide of a young Changsha woman, Miss Zhao, who slit her own throat on her wedding day to escape marriage to the man to whom her parents had betrothed her" (197).

74 Nor was it simply a case of elite males using feminist ideas as a means to their own liberation: young women themselves resisted the traditional ideology that had grounded such practices as footbinding and non-consensual marriage. See Rana Mitter, A Bitter Revolution: China's Struggle with the Modern World; Wang Zheng, Women in the Chinese Enlightenment: Oral and Textual Histories; Harriet Evans, "The Impossibility of Gender in Narratives of China's Modernity"; and Lydia Liu, Rebecca Karl, and Dorothy Ko, eds., The Birth of Chinese Feminism: Essential Texts in Transnational Theory. 
Would it not have been strange, patronizing-indeed, would it not have been orientalizing?- for a progressive anti-colonialist Westerner to refuse to listen to the vision her Chinese hosts offered of their own culture and their own future? If we look at her remarks on "la vieille Chine" (the old China) through the screen of multicultural "difference," we may see insensitivity; if we look at them through the lens of political economy, we will see that she is articulating a position in solidarity with views that, I submit, have every right to be understood as "Chinese."

It is certainly the case that Hu Shi, Lu Xun, Mao Dun, many others were influenced by study in and of "the West." And so indeed was the revolutionary generation, many of whom studied in France. ${ }^{75}$ But to see the May Fourth movement (and its Maoist legacy) as one more symptom of cultural imperialism would be to deny agency and intellect to the Chinese who created it.

It would also ignore the fact that women's official position in China in the 1950s was well in advance of any European country at that date. One did not find de Gaulle or Eisenhower arguing that women held up half the sky, or if they had said that, they would have been referring to women's role as dutiful wives and citizen mothers. ${ }^{76}$ Beauvoir's description of the Communist commitment to women, through new laws of marriage that went hand in hand with other attempts, such as land reform and collectivization, to break the system of private property, is validated by my reading of more recent feminist China scholars: their work echoes her claims that women's situation in China improved under Communism, and also corroborate her uncertainty about how fully these improvements would "take." It does seem fair to say that (old) materialist feminism, which saw an understanding of both gender and class (and of the link between them) as fundamental to attempts to overthrow an oppressive system, at that moment was closer to being put into practice in China than anywhere else on earth. ${ }^{77}$

75 See Paau Shiu-lam, “The Vogue of France Among Late Ch’ing Revolutionaries.”

76 The French communists hardly offered a viable alternative: in addition to discrediting themselves with respect to the Soviet "labor" camps, and later the Mahgreb, the PCF proved extremely conservative with respect to such issues as abortion and contraception. See for instance Christina Gilmartin, "Gender in the Formation of a Communist Body Politic," Wang Zheng, Finding Women in the State: A Socialist Feminist Revolution in the People's Republic of China, 1949-1964, and Xin Huang, The Gender Legacy of the Mao Era: Women's Life Stories in Contemporary China. It is good to remember that, as these scholars show, Maoist feminism was feminism, and that it was created and maintained by feminists. The story of Beauvoir and Chen Xuezhao is another data point here. 
Here, and throughout, I'm taking a different approach from that of Li-Hsiang Lisa Rosenlee, who writes in her book, Confucianism and Feminism: A Philosophical Interpretation:

The term Western feminist here primarily is used to refer to an ideological orientation that frames Chinese women's liberation in accordance with Western intellectual tradition. In this way, a feminist and/or sinologist who is de facto Chinese or have Chinese ancestry could fall into the category of "Western Feminist" and a feminist who is de facto Westerner could fall outside of that category insofar as their ideological orientation is concerned. So that the empirical problem that so and so is a Westerner yet advocates such and such position or so and so is a Chinese yet advocates such and such position can be resolved. ${ }^{78}$

This is a coherent outlook, and I am in no position to challenge her view that once one has peeled away Western frames there will be an authentic Confucian Chineseness left to see, which once subject to "rectification" (immanent critique) can serve as a resource for present-day feminists. Rosenlee's argument that Western roots for philosophical virtue ethics (Aristotle, Kant, Nietzsche) are no less in need of such rectification is indisputable. That most if not all of the activism and gains for women that took place in early twentieth century China did happen to show the influence of a Western frame and an attack on tradition becomes a purely "empirical" issue, which Rosenlee as a philosopher can properly set aside. However, that activism, and the possibility of a changed future, is what primarily interested Beauvoir, and it is also what interests me.

Rosenlee's re-analysis does find the subordination of women deeply encoded in Confucian texts and practices. Whether or not "wai" and "nei" map exactly onto Western "public" and "private," women were barred from activity in the "wai" in ways that were harmful to them; Chinese women minded that and said so. Rosenlee's history is particularly interested in moments of women's resistance and agency that might be difficult for outsiders to recognizenarratives of "virtuous women" where women writers gave other women conservative advice they hadn't followed themselves. Resistance to widow remarriage is a particularly interesting case where, she says, Western scholars, working from a view of Chinese women as helpless victims, misunderstood where women's true interests lie. I am less persuaded by the argument (which Dorothy Ko also makes) that the history of footbinding does not show Chinese

78 Li-Hsiang Lisa Rosenlee, Confucianism and Women: A Philosophical Interpretation, $161 \mathrm{n} 1$. 
women's erotic subordination, that it was an area of women's agency because women were active participants and it had a social meaning (and, in the work of Ko, an artistic value). ${ }^{79}$ Or rather, no, I do appreciate the agency involved: but I find Beauvoir's understanding of "complicity" a better way to theorize it.

Rosenlee does not refer to La longue marche, or to what Beauvoir has to say about China in The Second Sex and her autobiography. But she does say that she has found Beauvoir's "existentialists' deconstruction of traditional accounts of the 'essence' or 'nature' of a woman" foundationally helpful to her own project, in generating the problem of how "feminists [can] continue to use the category of 'woman' as a collective term to talk about gender oppression across cultural, racial, and class boundaries." ${ }^{\prime 00}$ She returns to Beauvoir also at the very end of her book: "In the end, this project eventually is personal. Like de Beauvoir, who wrote The Second Sex in order to answer the personal question of what it means to be a woman, I am trying to answer to myself what it means to be a Chinese Confucian woman." ${ }^{81}$

One possible conclusion one might draw is that "Confucius" will be no less, and no more, philosophically useful than "Hegel" or Kant: in both cases, the question becomes "what we make of what he made of us." In both cases, the modern feminist (wherever she comes from, or lives) will have to engage in what Maria Lugones called "contortions," to a quite significant degree. So perhaps the "feminism" in feminist philosophy is what is discovered in the course of performing those contortions? Perhaps the contortions are the feminism?

To my mind, unless one wants to commit the absurdity of calling the May Fourth generation "self-orientalists," or something (self-hating Orientals?), it becomes urgent once again to speak of intellectual hybridity, and of the fact that, as Shana Brown has put it, "modernity was created in different places ... all maps are anachronistic." 82 Again, this is Paul Gilroy's point, and Sam Bardaouil's, about the importance of understanding modernism and modernity as produced through two-way (really multi-way) intellectual exchanges between the colonized and the metropole, and James Clifford's point (following Leiris) about ethnic "authenticity" as an invented object. This seems particularly applicable to the interchanges of the 1950s: its Bandung humanist version could be seen, for instance, in Frantz Fanon's denunciation of "folklore" in Les damnés de la terre, or in Michel Leiris's essay, "L'ethnographe devant le colonialisme,"

79 Dorothy Ko, Cinderella's Sisters: A Revisionist History of Footbinding and Every Step a Lotus: Shoes for Bound Feet.

$80 \quad$ Rosenlee 150, 151.

81 Ibid., 159.

82 Shana Brown, Lecture, University of Hawaii, July 2014. 
where, as we saw, he speaks precisely of the ethical and political imperative to stand in solidarity with the colonized subject of today, the "évolué," rather than confining non-Western cultures to a zoo or museum in order for Westerners to appreciate and study them in their "authentic" but stagnant state. Beauvoir's commitment to that dynamic is equally clear in La longue marche:

The fact that pre-Columbian art is not perpetuated in New York City ateliers never wrung a tear from me, nor will I shed one when Peking has forgotten Sung cloisonné and Ming brocade. ${ }^{83} \ldots$

The visitor who comes to find out about China trains most of his attentions upon the unusual and unique aspects of her culture; but the Chinese themselves are infinitely more interested in developing the general knowledge they must have if they are to stand on a par with all other nations. ${ }^{84}$

And this connects to her attack on the right-wingers in France and Hong Kong who deplore the disappearance of what is picturesque and mysterious about "the old China": it is westerners, who know nothing about the real China, who want to preserve it as a kind of mirage or utopia.

Is then China doomed willy-nilly to ape the West? The truth is that they are drawing from it heavily.... Many civilized Western souls bemoan this; convinced of their definitive superiority, the idea of China remaining "different" tickles their fancy. China is, they wail, going to "become banal." They are very vague indeed about Chinese thought and art, their ignorance of the language and literature is total; but it's this mysteriousness that appeals to them, it looks something like infinity; they love to dream

83 “Je n'ai jamais déploré que New York ne perpétuât pas les arts précolombiens; je n'aurai pas de regrets quand Pékin oubliera le cloisonné Song ou les broderies Ming" (La longue marche 344-45, The Long March 355). This was not a new thought for Beauvoir, nor was it China-specific. See L'Amérique au jour le jour 1947 (262-83) for a similar view of Taos Pueblo, where she witnessed Native Americans performing traditional dances for the entertainment of tourists. Her visit to Portugal right after the war had led to a similar condemnation, in Pour une morale de l'ambiguité, of the dictator Salazar's assiduous preservation of handicrafts and vernacular architecture at the expense of funding human welfare, despite the extreme poverty in which most Portuguese were then living (Pour une morale de l'ambiguité 134-36, Ethics of Ambiguity 92-94).

84 "Le visiteur qui s'initie à la Chine s'intéresse surtout aux formes singulières de sa culture; mais les Chinois eux-mêmes sont essentiellement soucieux de développer le savoir universel qui leur est nécessaire pour s'égaler sur tous les plans aux autres nations" (La longue marche 349, The Long March 360). 
that in this otherwise banal world there is still a special somewhere yet full of unfathomable marvels. The Chinese, though, do not dream their culture, they live it; they sense its limitations; they also know those limitations may be surmounted; they are refusing to stay put in that supposed wonderland to which the perhaps innocent but none the less essentially contemptuous admiration of certain Westerners would assign them. ${ }^{85}$

As she said at the outset, she went to China not in search of some romantic mysterious East, not in search of the "Other," but in pursuit (and support) of political solutions. And she exposes the bad faith of those who, she says, would keep the Chinese peasant poor in the interest of the picturesque, those for example who miss the "Singsong Girls" of the now demolished brothels, which in 1920 held thousands of young women who had been kidnapped or sold by their indigent families; $; 6$ those who are nostalgic even for the dirt and squalor that have been (at least in theory) banished from Peking, which is now "aseptically

85 "La Chine est-elle donc condamnée bon gré mal gré à copier l'Occident? Le fait est qu'elle s'en inspire considérablement. Elle s'est transformée socialement et économiquement grâce aux sciences et aux techniques occidentales: pour s'exprimer dans sa nouveauté elle est obligée d'emprunter aux pays qui sont en avance sur elle. Beaucoup de civilisés occidentaux s'en désolent; convaincus de leur définitive supériorité, il leur plairait que la Chine demeurât 'différente.' Elle va 'se banaliser,' déplorent-ils. Ils ignorent tout de sa langue et de sa littérature, presque tout de sa pensée et de son art: mais précisément ce mystère prend à leurs yeux l'apparence de l'infini; ils aiment à rêver que quelque part au monde se perpétuent d'insondables merveilles. Les Chinois ne rêvent pas leur culture: ils la vivent; ils en éprouvent les limites; mais aussi ils savent que celles-ci peuvent être dépassées; ils refusent de se laisser enfermer dans le domaine que prétend leur assigner l'admiration ignorante et, en vérité, méprisante de certains Occidentaux" (La longue marche 352, The Long March 363, translation modified).

86 For example, in an early chapter, "The Discovery of Peking," she describes the quarter of "opium dens and brothels that exist no more": "As for the brothels, they numbered 277 in 1920, contained 3,130 girls divided into four classes according to their youth and beauty; they were bought while still very young from needy families, or they were simply kidnapped ... in return for gratuities, newspapers publicized them openly ... as if advertising a brand of laundry soap. Recounting their adventures, tourists of the period were cheerfully wont to extol the charm and gracious manners of those to whom they referred as 'Singsong girls"' (The Long March 41-2). [C'est là que se trouvaient naguère les lieux de plaisir et de débauche ... des fumeries d'opium, des bordels qui n'existent plus.... Quant aux bordels, en 1920 on en comptait 377, comprenant 3,130 pensionnaires, réparties en quatre classes selon leur jeunesse et leur beauté; on les achetait toutes jeunes à des familles indigentes, ou même on les kidnappait.... [L] es journaux leur faisaient une publicité ouverte ... comme s'il se fût agi d'une marque de lessive. Les touristes de l'époque se plaisent à vanter, dans leur récits de voyage, le charme et les manières décentes de celles qu'on appelait les "Sing-song girls" (La longue marche 38-9).] 
spic and span," 87 in contrast to Naples, Lisbon, Barcelona, even Chicago and New York. ${ }^{88}$ But "certain aesthetes, enamored of old China, miss the flies, the ragged people: 'No more beggars! why, this isn't Peking anymore,' one connoisseur exclaimed to me, reproach in his tone." 89 The direction of Beauvoir's criticism here strikes me as anti-Orientalist; that term had not been invented, but perhaps Sartre came close to it when he praised Cartier-Bresson's photographs of China as "neither lotus nor Loti." ${ }^{90}$ I find Beauvoir's version persuasive, and potentially far-reaching.

What holds together all the "fellow-traveling" literature, then and now, is the simple belief that there are viable political alternatives to capitalism, and that there is a viable role for literature and the arts to play that is not limited to shoring up the economic and social interests of the bourgeoisie. From that perspective, the book's most poignant moment occurs on the reviewing stand at the First of October parade: the delegation has been standing for four hours, barely noticing the passage of time, as thousands of dancers pay their respects to the Chinese leaders and celebrate the Revolution.

The parade continues. All the while watching it, we cast side-long glances at each other: Poles, Frenchmen, Italians, we were all bred on irony, taught to keep our emotions on a leash, and our sophistication includes the keenest unwillingness to be made a fool of; each of us wonders to himself whether he is all alone in feeling moved by the earnest joyousness of this crowd on the march. It is a relief to hear Infeld murmur: "When you see that, you don't much want to be a cynic any more."

87 "[R]igoureusement aseptisé" (La longue marche 40, The Long March 42).

88 "The travel agencies' slogans which in the West define the picturesque section of the city, narrow and evil-smelling little streets, does not apply here," and she contrasts Naples, Lisbon, Barcelona, Chicago and the Bowery: here there are no bums (The Long March 42-3). [Le slogan qui définit en Occident les pittoresques quartiers pauvres-"rues étroites et nauséabondes" — n'est pas de mise ici: on n'y respire pas une mauvaise odeur. Ces rues ne sont pas seulement incomparables avec les venelles de Naples, de Lisbonne, ou de Barcelone; on n'y voit pas comme dans les allées de Chicago voler de vieux journaux ou fumer les poubelles; on n'y rencontre pas ces "hommes oubliés" qui traînent sur la Bowery de New York (La longue marche 40, The Long March 42).]

89 "Certains esthètes, amoureux de l'ancienne Chine, regrettent les mouches, les haillons: 'Plus de mendiants! mais ce n'est plus Pékin!' m’a dit l'un d'eux avec blâme” (La longue marche 49, The Long March 52).

go "[S]ans lotus ni Loti" (Sartre, D'une Chine à l'autre, 8). The photographs were taken in 1948 and 1949 .

91 "Le défilé se poursuit. Tout en le regardant, nous nous observons les uns les autres: Polonais, Français, Italiens, nous avons tous l'ironie facile et la volonté arrêtée de n'être pas dupes; chacun se demande s'il est seul à se sentir touché par la sérieuse gaieté de cette 
Leiris's version in Fibrilles is more poetic: "And if, for once, we gave up our cynicism?"

In 2017, Chinese scholar Min Dongchao, while noting that "traveling theory" still tends to move from West to East, called on feminists to move beyond Said's original paradigm and pay attention to the "many other invisible discursive trajectories that link the development of gender theories and movements in the world that have so far been ignored."92 Uncovering a few such complex trajectories has been my project, and like Beauvoir's own it is not (I hope) a purely academic one. We might think further about how Beauvoir's on-theground feminist activism in France in the 1970s and 1980s, and everything the French MLF owes her for that work, was informed by what she learned in and about China. As with her other travels, we might see her less as "bringing theory," and more as seeking it. ("Not only has [Kahina] read your books, but now it is you who read hers"?) Of course she would not have said "theory": that is not her word, but ours. In La force des choses she said China had given her "schemata" and "keys" (des schémas, des clés); when she sent Kate Millett's delegation off to hear what Iranian feminists had to say, she spoke more simply of informations. But how does this look from the other side?

In the fall of 2016, I travelled to Beijing to present an earlier version of this chapter at a conference of historians. Afterwards, several members of the audience expressed surprise: they had expected from my title ("Beauvoir in China") that I would speak about Chinese translations and reception of The Second Sex; that Beauvoir herself had traveled to China in the 1950s, none of the Chinese historians knew. It seemed unlikely to me that Beauvoir's own work had had any significant impact on China. Certainly she did not actively seek to do so. As she describes it, the flow went in the other direction, and it was French readers she had sought to influence with La longue marche, to mobilize European support for China in the context of anti-colonialist struggle. But like Beauvoir, I went home and went to the library, and it turned out there was more to know.

foule en marche. Nous sommes soulagés d'entendre Infeld murmurer: 'Quand on voit ça, on n'a plus envie d'être cynique'" (La longue marche 414-15, The Long March 428).

92 Min Dongchao, Translation and Travelling Theory: Feminist Theory and Praxis in China, 4. Min's book helpfully connects flows of theory to recent flows of capital in service of economic "development." 
The current feminist scene in China is too dynamic and complex to characterize briefly, ${ }^{93}$ and (also like Beauvoir) I am limited to what I can read in English. So what follows is more a sketch than a full account. But from what I can tell, Beauvoir did have an influence; her reception was rather paradoxical; and again, the dimension of time has been key.

In 1955, Beauvoir reported, few Chinese had read her work (or Sartre's): they were invited as prominent intellectuals whose international cultural capital made their public support valuable. ${ }^{94}$ Later the regime's denunciation of "bourgeois feminism" as a "poisonous Western weed" blocked any uptake of her work. But after Mao's death, when the backlash against the Cultural Revolution increased receptiveness to "joining the international track" (in connection with Deng Xiaoping's economic reforms), Beauvoir does seem to have received attention from intellectuals and students.

The irony is this. Beauvoir herself had valued her Chinese experience because it helped clarify and develop the marxist-materialist side of her analysis. But in the 1980s Chinese feminists found her ideas helpful in detaching the women's movement from Maoist marxism, which they identified with the (now discredited) regime that had led to Cultural Revolution turmoil, and also in detaching their feminism from the activities of the All-China Women's Federation, which had functioned as an arm of the State. Beauvoir was embraced (especially by Li Xiaojiang, a highly influential writer and founder of the academic discipline of women's studies in China), as a theorist of woman's difference, as having drawn attention to the particular condition and experience of women, in ways that had been silenced by Maoist doctrines like "what men can do, women can do." In an article analysing successive translations of The Second Sex (in both Mainland China and Taiwan), Nicki Liu Haiping explains,

For Li Xiaojiang, a pioneer of Chinese feminism, Beauvoir's The Second Sex was attractive, not for its theme of "second sex," but for its theme of woman. For her, there was nothing earth-shattering about the observation of women's inferiority. However, for "woman" to appear in a book title in the early 1980 s in China was refreshing.... [It] came at a time when

93 For two very interesting, and very different, accounts, see Leta Hong Fincher, Betraying Big Brother: The Feminist Awakening in China and Xin Huang, The Gender Legacy of the Mao Era: Women's Life Stories in Contemporary China.

94 Chen Xuezhao had read The Second Sex - an ex-boyfriend who had stayed in France had sent it to her-but her comment in her autobiography is limited to wondering why he had done so. 
Chinese women were looking for something to support their struggle to break away from the grip of class theory. ${ }^{95}$

Dai Jinhua, another pioneering Chinese feminist, who found The Second Sex life-changing when she came across it in 1979, noted in retrospect (2001):

From a historical point of view, it is not hard to see that the appearance of Simone de Beauvoir, Le deuxième sexe and feminist theory in China was in fact situated in multiple mismatches with societal reality.... A serious dislocation herein was that Chinese feminists of the 1980 os used the term "female gender/second sex" to highlight the existence of gender difference rather than to reveal the absurdity of gender fundamentalism. They used it to break away from women's anonymous status under the principle that "men and women are the same."96

Many theorists, including Min Dongchao (taking off from Said), have emphasized the productive value of misreading. ${ }^{97}$ But Li's emphasis on difference in Beauvoir's account of women's experience is not really a misreading; or at least, it is no more of a misreading than those in the US who read Beauvoir as a liberal "equality feminist" indifferent to the specifics of women's embodiment. Beauvoir scholars increasingly discuss the complexity of her phenomenological picture of women's embodied experience. ${ }^{98}$ And indeed, early in the introduction to The Second Sex, Beauvoir did say, "It is clear that no woman can claim without bad faith to be situated beyond her sex,"99 although as Toril Moi noticed, the first English translation simply left that sentence out.

However, the earliest Chinese translation of The Second Sex (done in Taiwan, imported to the Mainland) was incomplete in the other direction: it omitted the entirety of volume one, and included only the second volume, "Women's

95 Nicki Liu Haiping, "Manipulating Simone de Beauvoir: A Case Study of the Chinese Translations of The Second Sex," 89.

96 Dai Jinhua, "Traces of Time: Simone de Beauvoir in China," 184, 185.

97 See also Tani Barlow's complex discussion of feminism as "catachresis," in The Question of Women in Chinese Feminism, and Xiaomei Chen, Occidentalism. Li's uptake of Beauvoir as a difference feminist is ironic, but perhaps no more so than than the way US feminists have embraced Mao's slogan, "women hold up half the sky," "the iron girl" ideal many Chinese women found oppressive rather than "empowering."

98 See for instance Sara Heinämaa, Toward a Phenomenology of Sexual Difference. See also Toril Moi, What is a Woman? for a discussion of how poorly Beauvoir's view maps onto 1980 os essentialism/contructionism debates in the US.

99 "Il est clair qu'aucune femme ne peut prétendre sans mauvaise foi se situer par-delà son sexe” (DS 1:13). See Toril Moi, “While We Wait.” 
Lived Experience."100 Could this help explain why Chinese feminists emphasized her account of female embodied subjectivity, rather than the philosophical critique she lays out in the introduction to volume one, which has been emphasized (indeed perhaps overemphasized) in Anglophone philosophical work?

It is the mark of a complex and fecund work of theory to sustain different interpretations. Still, there are limits, and Beauvoir would certainly not have agreed with what Li made of her account of sexual difference. ${ }^{101} \mathrm{Li}$ describes women's difference as essentially rooted in biology, especially in maternity; she argues that men and women evolved separately, and that "nature" thus requires different but complementary roles; she called on women to emphasize their femininity, and to take advantage of the new availability of female subjectivity through consumer culture. This has led Tani Barlow to characterize Li as a "market feminist"; Min Dongchao describes Li's corrective focus on the creation of feminine subjectivity more gently as part of a "cultural turn," a turn away from politics. More recently, Song Shaopeng has outlined ways Li's work dovetails with neo-liberalism. ${ }^{102}$

100 See Haiping for details and close analysis. See also two short pieces from the 2008 anthology, (Re)découvrir l'ouvre de Simone de Beauvoir: Sophie Zhang, "Beauvoir et la Chine" and Xin Miao, "Simone de Beauvoir et Le deuxième sexe en Chine." The earliest Chinese translations were based on Parshley's English version, and so was the first "complete" one, by Tao Tiezhu in 1998. Sophie Zhang spoke with his widow, who told her that Tao (not unlike Parshley) had died of exhaustion ("meurt d'épuisement") soon after it appeared. ("Un camarade homme, dévoué à la cause des femmes! Nous lui rendons hommage" says Zhang [337]). The first Chinese translation directly from French, by Kelu Zhang, was published in Shanghai in 2011.

101 The refusal of biological determinism, and rejection of femininity, seem basic to her theory; I am extrapolating also from her negative reaction to the "difference feminisms" of Julia Kristeva and Hélène Cixous.

Stepping back from the paradox of Li's reading, I notice another: US feminists virtuously goading one another to ritually denounce Beauvoir's "orientalism" at more or less the same time as Chinese feminists are deploying her work in ways they find productive.

102 See Li Xiaojiang, "Economic Reform and the Awakening of Chinese Women's Consciousness," originally published in Chinese in 1988; Barlow, The Question of Women in Chinese Feminism, 255-301; Li Xiaojiang, "With What Discourse Do We Reflect on Chinese Women." This last article, published in 1999, lays out very clearly and cogently why various Western feminist terms and ideas (such as "equality," "the personal is political," and "liberation") cannot easily be used in Chinese feminism, because of their Maoist history and resonances. See also Sharon Wesoky, "Bringing the Jia Back into Guojia: Engendering Chinese Intellectual Politics." Sharon Wesoky has kindly shared her student's translation of Song Shaopeng, "Capitalism, Socialism, and Women," which appeared in Chinese on the website Open Times. 
In retrospect, Chinese feminists (including Li herself) seem to have seen the limitations of this approach. As Dai Jinhua continues:

In the midst of the prelude to a profound social transformation at a different time in a different place, people could not predict where this process of saying farewell to the Cultural Revolution era, burying the socialist system and ending the rule of totalitarianism was going to lead China.... People could not predict that burying the socialist system did not necessarily mean burying and seeing off totalitarian rule forever. They could even less predict that this new process of capitalization pushed forward by a "communist party" was going to come at the inevitable expense of women's collective interest. ${ }^{103}$

To paraphrase Beauvoir, it is an error to view feminist theory as though things were stopped..$^{104}$

I said in my introduction, speaking of Beauvoir's reception in France and the US, that some scholars and activists praised Beauvoir as a feminist of equality, others as a feminist of difference, while others have damned her for being precisely one or the other of those things. Something similar appears to be true in China; or at least, she remains, internationally, a ground on which these questions are asked. Might this oscillation possibly suggest that there is a third way? or that when the pendulum swings too far in either direction, she can help to swing it back? Or, in any case, that without providing recipes-for anything - she reminds us to continue asking these questions, which we will have to answer for ourselves?

Min Dongchao's book proposes an "alternative traveling theory" that will work harder at fully understanding reception contexts, both spatially and temporally: uptake of a theory in a different place and/or time implies that it fills a need there, and then; but the need it fills at the point of reception may be quite different from the need it was created to fill. "Most literature on traveling theory deals with the discursive issue," she points out, but "[t]heories, especially

103 "Traces of Time," 184. Neo-liberalism in China has led to losses both for poor women (who have been deprived of the basic livelihood and safety net provided under communism) and for educated women, who face discrimination in the job market and the consequences of sexualization in the private sphere.

104 Interestingly, while both Dai in (2001) and Min (in 2014) end their analyses by lamenting the absence of socialist feminism from the current Chinese scene-an absence such theorists as Song Shaopeng are currently addressing - they do not see, or do not emphasize, the socialist dimensions of Beauvoir's own writing, any than most French or American readers have done. 
feminist theory, do not just travel to and in academic circles; they also travel to larger social movements." 105 On this view, that an account can become "dated" is a mark of its value, of the degree to which it is engaged with what is urgently real, with facts as well as myths.

Of course engaging with "facts" as they unfold in real time runs the risk of getting things terribly wrong, either because of one's own blind spots or simply because things change. But I hope even readers who do not feel any special urgency about "being fair to Beauvoir" will nonetheless see some value in the risks she took: the risk of listening to and trusting her sources, and the risk of hope.

What would happen if we read "dated" feminist works in that same spirit, not with "the hermeneutics of disapproval," 106 but with an eye to possible alliances and collaborations? what "chosen projects" might we then discover that we and they actually share? What if we focused less on the adequacy of various "frameworks" and more on what could be seen by looking inside the frame? What if the "datedness" of older works became, not a reason to dismiss them, but a spur to learn (and teach) more history?

Min's own chapter on Beauvoir adds yet another twist. After detailing the importance of Beauvoir's work to general Chinese developments in the late 1980 , and to her own developing understanding of feminism, she tells us something else: conversations with Chinese feminists have confirmed her suspicion that that the influence of The Second Sex did not include many people actually reading it. (As I said at the outset, that has been equally true in the US.)

This would not, by the way, have bothered Beauvoir. Her support for the 1970 generation of feminists, both in France and the US, was wholehearted and enthusiastic. But when John Gerassi asked her in 1976 about the fact that "Many people, especially in America, consider it [The Second Sex] the beginning of the contemporary feminist movement," she countered, "I don't think so," pointing out that most 1970 s activists were too young to have read the book when it appeared. "They may have become feminists for the reasons I explain in The Second Sex; but they discovered those reasons in their life experiences, not in my book."107

105 Min Dongchao, 6, 4.

106 The phrase is Susan Fraiman's.

107 John Gerassi, "The Second Sex: Twenty-five Years Later (Interview with Simone de Beauvoir)," 79. She was even blunter in 1983 when Liliane Lazar asked whether she thought $L a$ vieillesse had changed French attitudes to old age. She replied, "Non, je ne pense pas du tout. Je ne pense pas qu'un livre puisse vraiment changer les choses." (Not at all. I don't think a book can really change things.) "Conversation avec Simone de Beauvoir," 11. 
And yet, books do matter.

In the spring of 2015, a group of young women were arrested in Beijing for protesting sexual harassment; after an international campaign of support, they were released. One member of their group, Xiao Meili, wrote an Op-Ed piece for the New York Times in which she credited Beauvoir by name.

When I was growing up in the 199os in Sichuan Province, I found many cultural traditions and practices puzzling. At home, I addressed my mother's parents as "waipo" and "waigong," or "outside grandma" and "outside grandpa," because I was told that my father's family mattered more. In school, my teachers held higher academic expectations for boys than they did for girls because they believed boys were smarter than girls. .... Many universities openly excluded girls from majors such as marine engineering and geological exploration.... I constantly saw want ads that either excluded women or specified that women applicants needed to be tall and attractive...

Many took this entrenched discrimination for granted, but I didn't. As a sophomore in college, I became interested in feminism and began reading Simone de Beauvoir's The Second Sex and other famous feminist works. Like a nearsighted person with new glasses, I began to see clearly, and many of the things that puzzled me growing up were explained by feminism.... ${ }^{108}$

It would be difficult to disentangle what is "Chinese" and what is "Western" in Xiao Meili's account, either in the discrimination she describes or in the feminist impulse to re-vision and resistance. Perhaps disentangling that is not really the best use of anyone's energy. And if, for once, we gave up our cynicism?

Of course "we" wouldn't say that "now."

If not now, when?

Meryl Altman

December 31, 2019

108 Xiao Meili, “China’s Feminist Awakening," Op-Ed, New York Times, May 132015. 